\title{
PEMBAKARAN PREMIKS UAP MINYAK KELAPA DALAM HELE-SHAW CELL
}

\author{
Hadi Saroso \\ Departemen Teknik Kimia, Politeknik Negeri Malang, Jl. Soekarno Hatta 64145, Malang, Indonesia \\ Email: hadi.saroso@polinema.ac.id
}

\begin{abstract}
Abstrak
Karakteristik pembakaran minyak kelapa diamati secara eksperimental oleh penguapan minyak di boiler kemudian mencampurnya dengan udara sebelum dibakar di berbagai rasio kesetaraan dalam Hele-shaw Cell. Hasil penelitian menunjukkan bahwa minyak kelapa cenderung untuk masuk ke gliserol dan asam lemak karena reaksi hidrolisis menghasilkan propagasi api, dimana api asam lemak merambat pertama kemudian gliserol api. Ledakan-mikro terjadi ketika uap air dari asam lemak pembakaran diserap oleh gliserol, dan pemanasan yang lebih tinggi karena kecepatan api yang lebih tinggi menghasilkan ledakan-mikro.
\end{abstract}

Kata kunci : pembakaran premiks, minyak kelapa, gliserol, asam lemak, mikro-ledakan

\begin{abstract}
Coconut oil combustion characteristic is observed experimentally by evaporating oil in the boiler then mix it with air before being burned at various equivalence ratios in the Hele-shaw cell. The result shows that, coconut oil tends to break into glycerol and fatty acid due to hydrolysis reaction producing the flame propagation, where the fatty acid flame propagates first then glycerol flame. Micro-explosion occurs when moisture from fatty acid combustion is absorbed by glycerol, and higher heating due to higher flame speed produces more micro-explosion.
\end{abstract}

Keywords : Premixed combustion, coconut oil, glycerol, fatty acid, micro-explosion

\section{Pendahuluan}

Motivasi untuk penelitian ini berasal dari perilaku rambat api yang berkaitan dengan mikroledakan minyak multi-komponen, di mana api asam lemak merambat pertama kemudian api gliserol dan uap air terjebak antara asam lemak dan gliserol. Sehubungan dengan pembakaran minyak multi-komponen, Cornet dan Turner menyatakan bahwa kualitas sayur bahan bakar minyak ditentukan oleh sifat sifat fisik dan kimia seperti volatilitas, difusivitas, dan reaktivitas [3]. Pembakaran minyak kelapa adalah sangat menarik untuk aplikasi industri dan Mesin diesel. Namun, pembakaran minyak kelapa langsung memiliki banyak masalah yang berhubungan dengan viskositas yang sekitar sepuluh kali lebih tinggi biodiesel [6]. Viskositas tinggi dari minyak sayur, terutama minyak kelapa mengandung asam lemak dan gliserol. Agarwal [2] menyatakan bahwa pemanasan awal adalah salah satu cara untuk menghasilkan proses pembakaran minyak jarak di diesel mesin. Temuan penelitian menunjukkan bahwa minyak kelapa dapat dipanaskan langsung digunakan untuk menggantikan bahan bakar diesel dan tidak memerlukan modifikasi mesin utama [8]. Tampaknya bahwa di masa depan, minyak kelapa pembakaran akan menjadi bahan bakar alternatif. Studi lain adalah menggambarkan efisiensi mesin diesel dengan menggunakan minyak sayur langsung [7]. Pengaruh suhu tinggi di beberapa bahan bakar komponen pembakaran telah dipelajari oleh Xu G [11]. Sebuah studi analitis telah dilakukan untuk mengidentifikasi pembakaran karakteristik propanol dicampur dengan gliserol pada mengurangi daya apung [4]. Perbedaan antara titik didih propanol dan gliserol menyebabkan mikro-ledakan.Mikro-ledakan mempertahankan terjadi di minyak kelapa karena asam lemak dan gliserol dalam minyak kelapa memiliki titik didih yang berbeda.

Di nomor Lewis tinggi, difusi kecil Koefisien massa mengurangi jumlah air diserap, dan di nomor rendah Lewis, massa yang lebih besar koefisien difusi peningkatan laju kehilangan air ke atmosfer, mengurangi konsentrasi air dalam api. Akibatnya, tingkat penyerapan dapat memaksimalkan moderat jumlah Lewis [12]. Ini telah diidentifikasi dalam beberapa penelitian, salah satu dilakukan oleh Wardana [10] yang meneliti karakteristik pembakaran dari tetesan minyak jarak di berbagai suhu, yang jarak tetesan minyak menjalani dua tahap pembakaran. Munculnya ledakan-mikro terjadi sesaat sebelum pembakaran Langkah kedua dan hal itu terjadi lebih sering, karena minyak peningkatan suhu.Gliserol memiliki didih yang lebih tinggi titik dari asam lemak yang menyebabkan masalah dalam pemanasan awal, dan juga menyerap air dari asam lemak pembakaran menghasilkan mikro-ledakan. Kang meneliti efek dari kehilangan panas dari laminar api premixed pembakaran momentum dalam celah sempit [5]. 
Ditemukan bahwa dua faktor bermain kompleks peran dalam menentukan bentuk ketidakstabilan seluruh sel. Untuk membuat proses efisien dalam sangat stabil premixed pembakaran, mikroledakan memainkan peran penting dalam kecepatan pembakaran.

Artikel ini disajikan untuk studi difokuskan pada identifikasi mikro-ledakan dalam minyak kelapa pembakaran premixed. Uap air adalah sangat menarik hal yang mempengaruhi perpindahan massa dan transportasi lainnya. Itu perbedaan suhu dipicu oleh ketidakstabilan propagasi api juga dapat memicu bahan kimia Reaksi drastis. Beberapa penelitian telah dilakukan untuk memahami mikro-ledakan apipropagasi [9]. Beberapa penelitian juga telah dilakukan pada premixed pembakaran bahan bakar multi-komponen [1]. Namun, sangat sedikit dapat ditemukan mengenai mikro-ledakan di kelapa premixed minyak bakar dalam sel Heleshaw. Oleh karena itu, penelitian ini berfokus pada mengidentifikasi karakteristik kelapa premixed minyak pembakaran dalam Hele-shaw cell.

\section{Metodologi Penelitian}

Peralatan eksperimen dan prosedur percobaan

Penelitian ini dilakukan dengan menggunakan satu set peralatan eksperimen seperti yang ditunjukkan pada gambar 1 . Ruang bakar terbuat dari kaca akrilik dan pelat baja dengan dimensi $500 \times 200 \times 10 \mathrm{~mm}$ dengan penyala di atas dan di bagian bawah. Tabung pelimpah digunakan untuk mengumpulkan air dari pembakaran ruang.Boiler digunakan untuk menguapkan minyak kelapa. Pengontrol suhu digunakan untuk mengontrol minyak pemanas. Udara dari kompresor dengan uap minyak kelapa dari boiler memberikan rasio setara $(\Phi)=1,35 ; 1,23 ; 1,15 ; 1,05 ; 1,006 ; 0,95$; 0.88 . Kamera CCD kecepatan tinggi digunakan untuk merekam bentuk rambat api dalam ruang pembakaran.

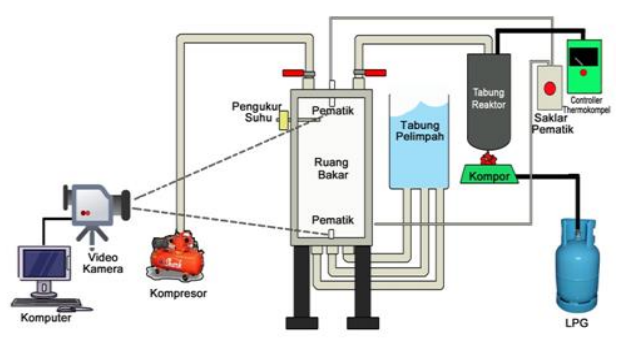

Gambar 1. Skema alat penelitian

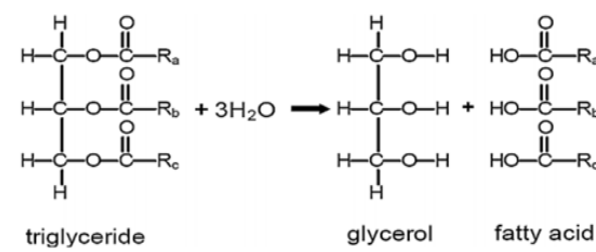

Gambar 2. Reaksi Hidrolisis Trigliserida

Tabel 1. Komposisi asamlemak uap minyak kelapa ( $\pm 200^{\circ} \mathrm{C}$ )

\begin{tabular}{|l|c|l|l|}
\hline $\begin{array}{l}\text { Asam } \\
\text { lemak }\end{array}$ & $\begin{array}{l}\text { No.carbon::No. } \\
\text { ikatan dobel }\end{array}$ & Rumus & $\begin{array}{l}\text { Komposisi } \\
(\%)\end{array}$ \\
\hline As.laurik & $12: 0$ & $\mathrm{C}_{12} \mathrm{H}_{24} \mathrm{O}_{2}$ & 40,35 \\
\hline $\begin{array}{l}\text { As. } \\
\text { miristik }\end{array}$ & $14: 0$ & $\mathrm{C}_{14} \mathrm{H}_{28} \mathrm{O}_{2}$ & 11,45 \\
\hline $\begin{array}{l}\text { As. } \\
\text { kaprilik }\end{array}$ & $8: 0$ & $\mathrm{C}_{8} \mathrm{H}_{16} \mathrm{O}_{2}$ & 18.13 \\
\hline $\begin{array}{l}\text { Asam } \\
\text { kaprik }\end{array}$ & $10: 0$ & $\mathrm{C}_{10} \mathrm{H}_{20} \mathrm{O}_{2}$ & 14,63 \\
\hline
\end{tabular}

Analisa GCMS

\section{Sifat dan Struktur kimia minyak kelapa}

Rekaman dari kamera video dipindahkan ke Compact Disc (CD) dalam file AVI. Kemudian, dengan menggunakan Software Pinnacle, gambar bergerak diekstraksi menjadi serangkaian gambar statis diatur secara kronologis dari awal api sampai api mencapai akhir dinding. Setiap komposisi campuran antara udara dan bahan bakar memberikan pola yang berbeda dari gambar api yang digambarkan dalam gambar 3. Bentuk api menggambarkan api perambatan. Dengan menggunakan software Adobe Photoshop CS3 jarak rambat api dan volume gas yang dibakar antara berbagai propagasi api di setiap frame diperkirakan seperti pada gambar 4, 5 dan 6 . Perilaku ketidakstabilan pembakaran dianalisis berdasarkangeometri api.

\section{Hasil dan Pembahasan}

Dari percobaan pada perambatan api campuran uap minyak kelapa-udara dengan ekivalensi rasio $(\Phi)=1,35 ; 1,23 ; 1,15 ; 1,05$; 1,$005 ; 0,95 ; 0,88$ dilakukan perekaman data percobaan dan hasil percobaan, dengan hasil perekaman berupa file film. Dari file film tersebut diubah menjadi file gambar.

\section{Rambat Api pada Penyala Atas}

Pada penyala atas, dengan mematik campuran uap minyak kelapa-udara terjadi rambatan api, dimana frame yang disusun secara berurutan dengan periode waktu antara dua frame 0,034 detik. Api asam lemak merambat lebih dahulu kemudian api gliserol. Karena berat molekul asam lemak lebih besar dari gliserol, akibatnya api asam lemak berada dibawah dan api gliserol berada diatas. Asam lemak dengan reaksi pembakaran menghasilkan uap air, dimana uap air 
diserap oleh gliserol yang menghasilkan ledakanmikro. Pada ekivalensi $(\Phi)=1,35 ; 1,23 ; 1,15$; 1,$05 ; 1,005 ; 0,95 ; 0,88$ pergerakan api merambat kebawah sampai 1,0 detik; 0,862 detik; 0,758 detik; 0,793 detik; 0,724 detik; 0,1,204 detik; 1,510 detik. Pada $\Phi=1,35$ dan 1,23 menunjukkan semakin besar konduksi termal bahan bakar maka api semakin tebal dan laju reaksinya lambat sehingga rambat api berwarna abu-abu dibagian bawah dan orange dibagian atas.

a) $\Phi=1,35$

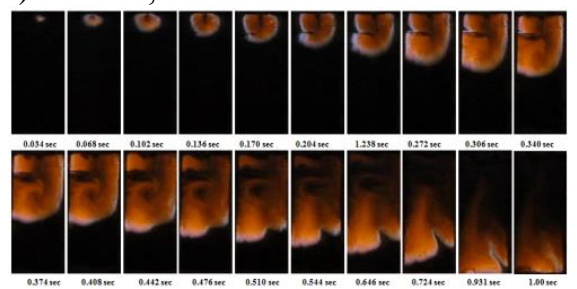

b) $\Phi=1,23$

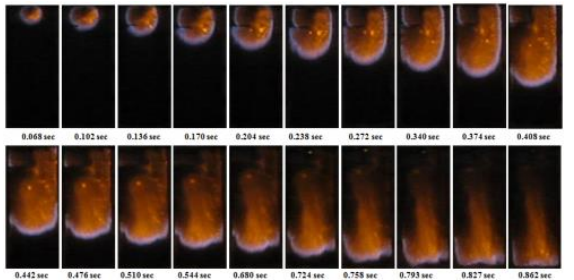

Gambar 3. Rambat api premiks uap minyak kelapaudara dengan penyalaan ataspada ekivalensi rasio a) $\Phi=1,35$; b) $\Phi=1,23$

Pada $\Phi=1,15 ; 1,05 ; 1,006$ (stabil) semakin kecil konduksi termal bahan bakar maka api semakin tipis dan laju reaksinya cepat. sehingga rambat api berwarna biru putih dibagian bawah dan merah tua dibagian atas (gambar 4).

a) $\Phi=1,15$

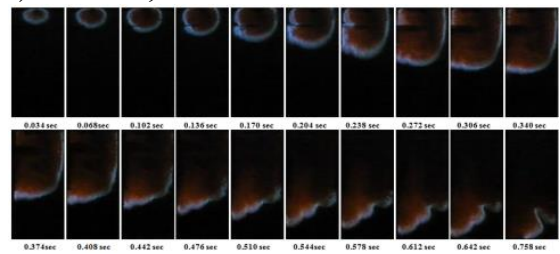

b) $\Phi=1,05$
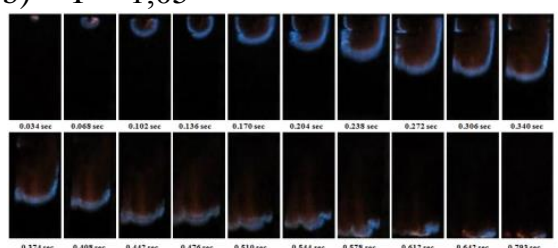

c) $\Phi=1,05$

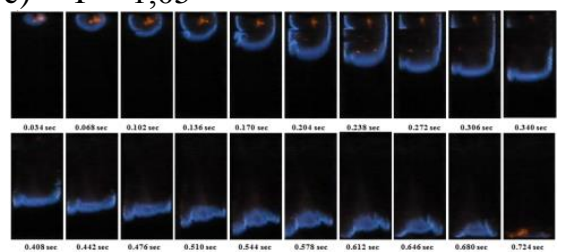

Gambar 4. Rambat api premiks uap minyak kelapaudara dengan penyalaan atas pada ekivalensi rasio. a). $\Phi=1,15 ; b) . \Phi=1,05 ; c) . \Phi=1,006$

Pada $\Phi=0,95 ; 0,88$; semakin panjang rantai karbon asam lemak maka semakin banyak udara yang dibutuhkan dan semakin tinggi temperatur penguapan. Sekali lagi ini menunjukkan bahwa gliserol membutuhkan banyak udara untuk membakar sehingga stabil, dan rambat api berwarna ungu tua bagian atas dan api bagian bawah berwarna abu-abu tua (gambar 5).

a) $\Phi=0,95$

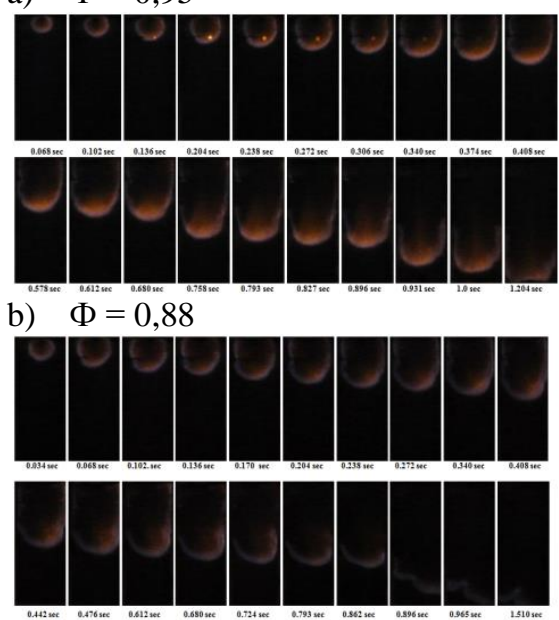

Gambar 5. Rambat api premiks uap minyak kelapaudara dengan penyalaan atas pada ekivalensi rasio $(\Phi)$. a). $\Phi=0.95 ;$ b). $\Phi=0,88$;

\section{Rambat Api pada Penyala Atas}

Pada penyala bawah,dengan mematik campuran uap minyak kelapa-udara terjadi rambatan api. Api asam lemak disusul api gliserol merambat keatas, kemudian gas $\mathrm{CO}_{2}$ merambat keatas masuk kedaerah reaksi yang menghambat rambatan api. Karena gliserol menyerap air akibatnya gliserol lebih berat dari asam lemak sehingga api asam lemak berada di atas dan api gliserol berada di bawahnya.

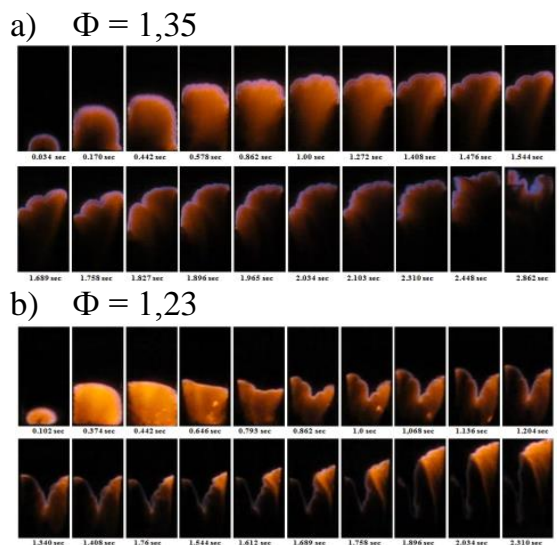

Gambar 6. Rambat api premiks uap minyak kelapaudara dengan penyalaan bawah pada ekivalensi rasio. a). $\Phi=1,35$; b). $\Phi=1,23$;

Asam lemak dengan reaksi pembakaran menghasilkan uap air, dimana uap air diserap oleh 
gliserol yang menghasilkan ledakan-mikro. Pada ekivalen $(\Phi)=1,35 ; 1,23 ; 1,15 ; 1,05 ; 1,005 ; 0,95$; 0,88 pergerakan api merambat kebawah sampai 2.862 detik, 2.310 detik; 2.241 detik; 2.517 detik; 2.103 detik; 2.862 detik, 3.837 detik. Pada $\Phi=$ 1,$35 ; 1,23$, semakin besar konduksi termal bahan bakar maka api semakin tebal dan laju reaksinya lambat sehingga rambat api berwarna abu-abu dibagian bawah dan orange di bagian atas gambar 6 .

Pada $\Phi=1,15 ; 1,05 ; 1,006$ (stabil), semakin kecil konduksi termal bahan bakar maka api semakin tipis dan laju reaksinya cepat, sehingga rambat api berwarna biru putih dibagian bawah dan merah tua di bagian atas (gambar 7).

a) $\Phi=1,15$

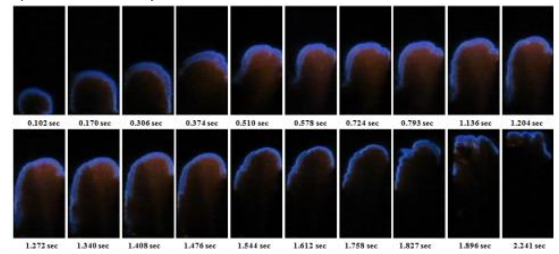

b) $\Phi=1,05$

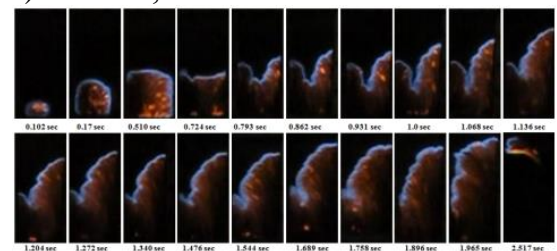

c) $\Phi=1,006$

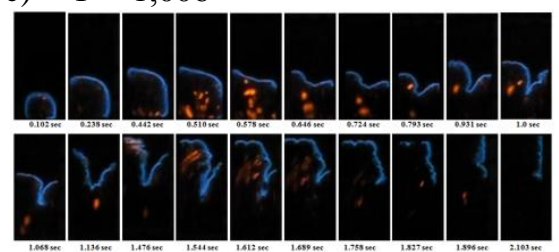

Gambar 7. Rambat api premiks uap minyak kelapaudara dengan penyalaan bawahpada ekivalensi rasio. a). $\Phi=1,15 ; b) . \Phi=1,05 ; c) . \Phi=1,006$.

Pada $\Phi=0,95$ dan $\Phi=0,88$, semakin panjang rantai karbon asam lemak maka semakin banyak udara yang dibutuhkan dan semakin tinggi temperature penguapan. Sekali lagi ini menunjukkan bahwa gliserol membutuhkan banyak udara untuk membakar sehingga stabil pada rambat api berwarna ungu tua bagian bawah dan api bagian atas berwarna abu-abu tua (gambar 8).

a) $\Phi=0,95$

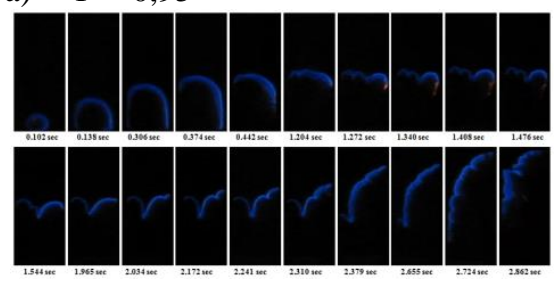

b) $\Phi=0,88$

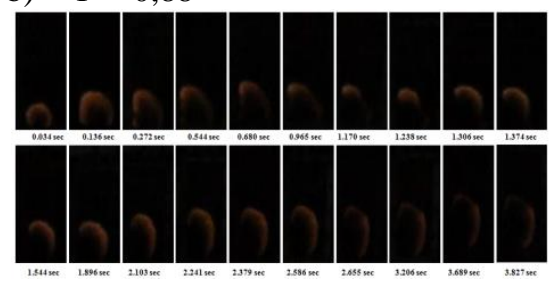

Gambar 8. Rambat api premiks uap minyak kelapaudara dengan penyalaan bawah pada ekivalensi rasio. a). $\Phi=0,95 ;$ b). $\Phi=0,88$.

\section{Pengaruh ekivalen rasio $(\Phi)$ terhadap Kecepatan Rambat Api}

Gambar 9 menunjukkan jarak api rata-rata terhadap waktu di berbagai equivalence ratio $(\Phi)$ pada penyala atas. Pada $\Phi=1,006$ terlihat kemiringan kurva lebih besar, jarak api konstan pada 0,646 detik sampai 0,680 detik. Pada $\Phi=$ 1,006 hal ini disebabkan gradient temperatur yang lebih tinggi oleh 4 komponen besar asam lemak yang ada di bahan bakar minyak kelapa tabel 1 . Panjang rantai karbon asam lemak membutuhkan banyak udara untuk proses pembakaran sempurna. Oleh karena itu kecepatan pembakaran meningkat dengan kemiringan lebih besar. Karena rambatan api cepat, akibatnya gliserol tidak sempat menyerap air dengan panas yang lebih tinggi, sehingga menimbulkan ledakan-mikro yang terang sedikit dan api asam lemak berwarna biru terang dibagian bawah dan merah gelap dibagian atas, sehingga api lebih panas yang maksimal.

Gambar 9 menunjukkan jarak api rata-rata terhadap waktu di berbagai equivalence ratio $(\Phi)$ pada penyala bawah.Pada $\Phi=1,006$ terlihat kemiringan kurva lebih besar, penundaan jarak api pada 0,442 detik sampai 0,793 detik, 1,827 detik sampai 1,896 detik dan nyala api berwarna biru muda Hal ini disebabkan densitas rendah sehingga konduksi termal bahan bakar lebih kecil maka api semakin tipis dan laju reaksinya cepat. Disamping itu gliserol berkesempatan lebih banyak menyerap air lebih banyak, karena gas $\mathrm{CO}_{2}$ yang menghambat laju reaksi sehingga menimbulkan ledakan-mikro yang banyak. Ledakan-mikro membuat stabil nyala api yang berwarna biru terang (gambar 9) dan panas lebih tinggi, akibatnya rambatan api lebih cepat. 


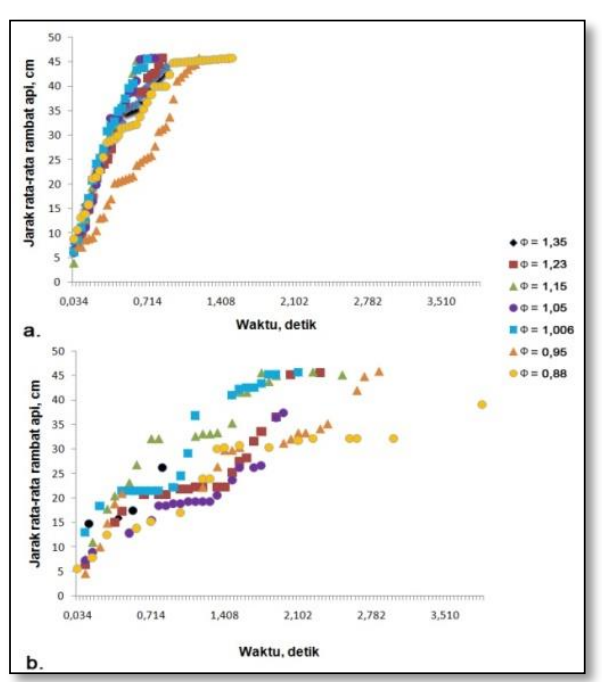

Gambar 9. Variasi jarak rata-rata dengan waktu pada penyalaan a. atas dan penyalaan b. bawah berbagai ekivalensi rasio

Kecepatan rambat api maksimum dengan ekivalen rasio disajikan pada gambar 10. Pada penyala atas kecepatan rambat api lebih cepat dari pada penyala bawah. Hal ini disebabkan bahwa pada penyala bawah gas $\mathrm{CO}_{2}$ merambat keatas memasuki daerah reaksi sehingga menghambat laju reaksi. Akibatnya kecepatan rambat api menjadi lambat.

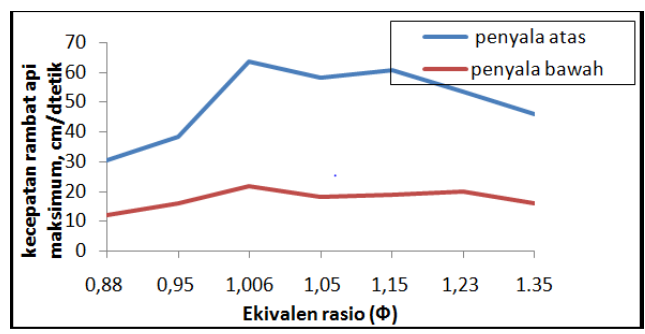

Gambar 10. Variasi kecepatan rambat api maksimum dengan ekivalen rasio pada penyalaan atas dan penyalaan bawah

\section{Pengaruh ekivalen rasio $(\Phi)$ terhadap Jumlah partikel ledakan-mikro}

Gambar 11 menunjukkan variasi jumlah ledakan-mikro terhadap waktu rambat api pada beberapa nilai $\Phi$ dengan penyala atas minyak kelapa yang di analisis dari gambar $3 ; 4 ; 5$. Pada Gambar 11 terlihat jumlah ledakan-mikro lebih banyak, pada $\Phi=1,006$ waktu perambatan 0,034 detik sampai 0,068 detik, pada $\Phi=1,23$ waktu perambatan 0,068 detik sampai 0,102 detik, pada $\Phi=1,15$ waktu perambatan 0,136 detik sampai 0,170 detik, pada $\Phi=1,23$ waktu perambatan 0,170 detik sampai 0,544 detik. Sedangkan jumlah ledakan-mikro yang maksimal terjadi5 buah pada 0,102 detik, 0,272 detik dan 0,408 detik. Hal ini disebabkan pada $\Phi=1,23$ semakin besar konduksi termal bahan bakar maka api semakin tebal dan laju reaksinya lambat.
Karena rambatan api lambat, akibatnya gliserol berkesempatan menyerap air, sehingga menimbulkan jumlah ledakan-mikro banyak yang kurang terang dan rambat api berwarna abu-abu dibagian bawah dan orange dibagian atas.

Gambar 11 menunjukkan variasi jumlah ledakan-mikro terhadap waktu rambat api pada beberapa nilai $\Phi$ dengan penyala bawah minyak kelapa yang di analisis dari gambar.6; 7; 8. Pada gambar 11, pada terlihat jumlah ledakan-mikro lebih banyak, waktu perambatan 0,102 detik sampai 0,238 detik dan 0,374 detik sampai 0,646 detik, pada $\Phi=1,006$ waktu perambatan 0,238 detik sampai 0,306 detik dan 0,646 detik sampai 0,793 detik. Sedangkan jumlah ledakan-mikro yang maksimal terjadi 9 buah pada 0,272 detik. Hal ini disebabkan pada $\Phi=1,006$ densitasnya rendah karena konduksi termal bahan bakar menjadi kecil maka api menjadi tipis dan laju reaksinya cepat. Karena gas $\mathrm{CO}_{2}$ merambat keatas masuk ke daerah reaksi yang menggangunya dan konduksi termal kecil, sehingga menghambat laju reaksi dan terjadi rambatan api yang lambat. Akibatnya gliserol berkesempatan lebih banyak menyerap air, sehingga menimbulkan jumlah ledakan-mikro banyak yang lebih terang dan rambat api berwarna biru terang dibagian bawah dan merah gelap di bagian atas.

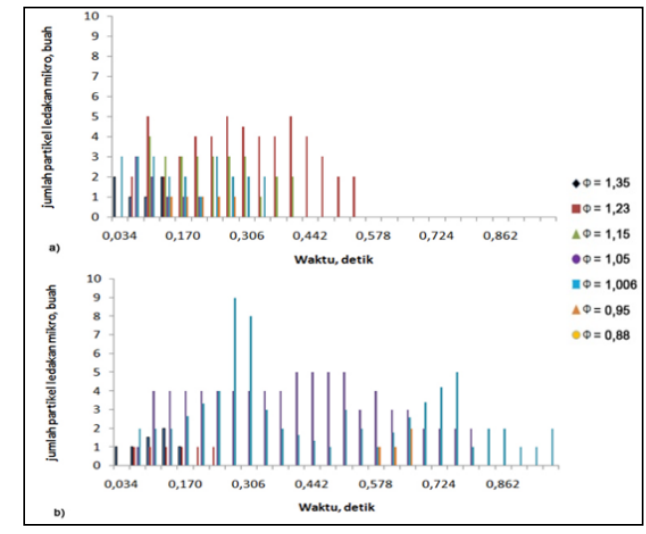

Gambar 11. Jumlah partkel ledakan-mikro pada penyalaan atas (a) dan penyalaan bawah (b) berbagai ekivalen rasio

Jumlah partikel ledakan-mikro maksimum dengan ekivalen pada penyala atas dan penyala bawah disajikan pada gambar 12. Pada penyala atas jumlah partikel ledakan-mikro pada $\Phi=1,23$ dan $\Phi=1,15$ lebih banyak, untuk $\Phi=1,35$; $\Phi=$ 1,$05 ; \Phi=1,006$ dan $\Phi=0,95$ pada penyala bawah. Hal ini disebabkan bahwa pada penyala bawah uap air diserap oleh gliserol sehinga terjadi jumlah partikel ledakan-mikro. Sedangkan pada penyala atas, untuk $\Phi=1,23$ dan $\Phi=1,15$ jumlah partikel ledakan-mikro lebih banyak, karena gliserol yang menyerap uap air kecepatan rambat api lebih cepat dari pada penyala bawah sehingga 
terjadi jumlah partikel ledakan-mikro lebih banyak dan tidak terang. Untuk $\Phi=1,35 ; \Phi=$ 1,$05 ; \Phi=1,006$ dan $\Phi=0,95$ pada penyala bawah jumlah partikel ledakan-mikro lebih banyak, karena gas $\mathrm{CO}_{2}$ merambat keatas memasuki daerah reaksi sehingga menghambat laju reaksi. Akibatnya uap air diserap oleh gliserol sehingga terjadi jumlah partikel ledakan-mikro lebih banyak dan lebih terang, karena penundaan /reaksi lambat.

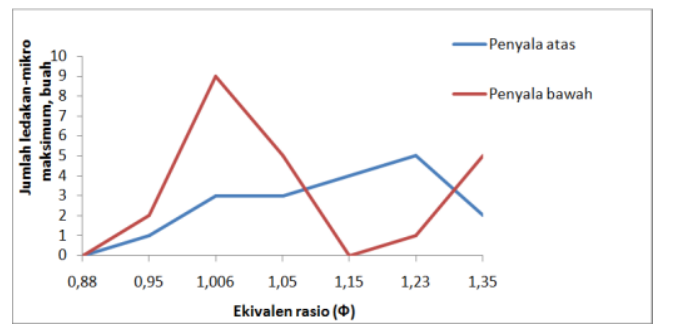

Gambar 12.Variasi jumlah partikel ledakan-mikro maksimum dengan ekivalenpada penyalaan atas dan penyalaan bawah

\section{Pengaruh Equalance ( $\Phi)$ terhadap Diameter rata-rata ledakan-mikro.}

Gambar 13 menunjukkan variasi diameter rata-rata ledakan-mikro terhadap waktu rambat api pada beberapa nilai $\Phi$ dengan penyala atas minyak kelapa yang di analisis dari Gambar 3; 4; 5. Pada Gambar 13 terlihat diameter rata-rata ledakan-mikro lebih banyak, pada $\Phi=1,35$ waktu perambatan 0,034 detik sampai 0,136 detik, pada $\Phi=0,95$; untuk 0,136 detik sampai 0,170 , pada $\Phi=1,23$ waktu perambatan 0,170 detik sampai 0,204 detik dan 0,340 detik sampai 0,544 detik Sedangkan pada $\Phi=1,006$ waktu merambat 0,204 detik sampai 0,340 detik dan juga menunjukkan bahwa diameter rata-rata $21,53 \mathrm{~mm}$ pada 0,408 detik. Hal ini disebabkan Pada $\Phi=$ 1,006 semakin sedikit konduksi termal bahan bakar maka api semakin tipis dan laju reaksinya cepat. Karena rambatan api cepat, akibatnya gliserol berkesempatan menyerap air dengan panas yang lebih tinggi tinggi, sehingga menimbulkan diameter rata-rata ledakan-mikro yang terang sedikit dan rambat api berwarna biru terang dibagian bawah dan merah gelap dibagian atas.

Gambar 13 menunjukkan variasi diameter ledakan-mikro terhadap waktu rambat api pada beberapa nilai $\Phi$ dengan penyala bawah. Pada $\Phi$ = 1,006 dapat dilihat bahwa ketika api merambat kebawah terdapat diameter ledakan-mikro rataratayang terbesar dan lebih terang dengan ratarata $41,19 \mathrm{~mm}$ pada 1,170 detik. Hal ini disebabkan semakin kecil konduksi termal bahan bakar maka api semakin tipis dan laju reaksinya cepat. Karena gas $\mathrm{CO}_{2}$ merambat keatas masuk ke daerah reaksi yang menggangunya dan konduksi termal kecil, sehingga menghambat laju reaksi dan terjadi rambatan api yang lambat. Akibatnya gliserol berkesempatan lebih banyak menyerap air, sehingga menimbulkan diameter rata-rata ledakan-mikro banyak yang lebih terang dan rambat api berwarna biru terang di bagian bawah dan merah gelap di bagian atas.

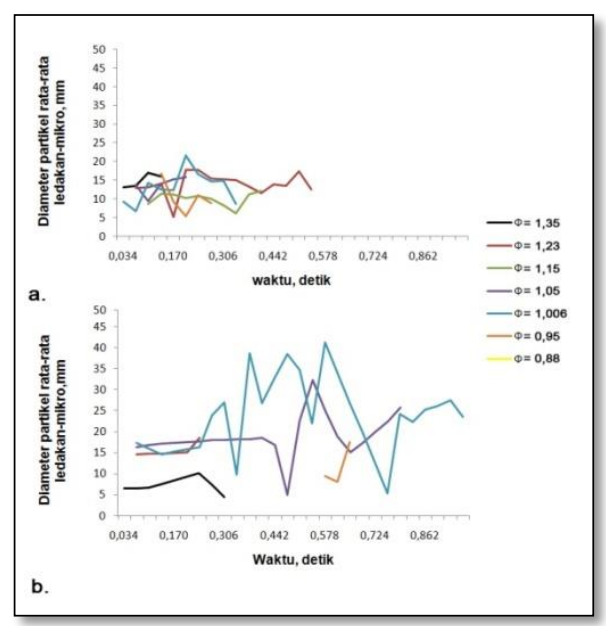

Gambar 13. Variasi diameter ledakan-mikro dengan waktu pada penyalaan a. atas dan penyalaan b. bawah berbagai ekivalen rasio berbagai ekivalen rasio

Diameter partikel ledakan-mikro maksimum dengan ekivalen pada penyala atas dan penyala bawah disajikan pada gambar 14. Pada penyala atas diameter partikel rata=rata ledakan-mikro pada $\Phi=1,35$ dan $\Phi=1,15$ lebih besar, untuk $\Phi$ $=1,05$ dan $\Phi=1,006$ pada penyala bawah. Hal ini disebabkan bahwa pada penyala bawah uap air diserap oleh gliserol sehinga terjadi diameter partikel rata-rata ledakan-mikro. Sedangkan pada penyala atas, untuk $\Phi=1,35$ dan $\Phi=1,15$ diameter partikel rata-rata ledakan-mikro lebih besar, karena gliserol yang menyerap uap air kecepatan rambat api lebih cepat dari pada penyala bawah sehingga terjadi diameter partikel rata-rata ledakan-mikro lebih besar dan lebih terang. Untuk $\Phi=1,05$ dan $\Phi=1,006$ pada penyala bawah diameter partikel rata-rata ledakan-mikro lebih besar, karena gas $\mathrm{CO}_{2}$ merambat keatas memasuki daerah reaksi sehingga menghambat laju reaksi. Akibatnya uap air diserap oleh gliserol sehingga terjadi diameter partikel rata-rata ledakan-mikro lebih besar dan lebih terang, karena dengan penundaan atau reaksi lambat pada $\Phi=1,15$ tidak terjadi ledakanmikro yang disebabkan kekurangan udara untuk membakar. 


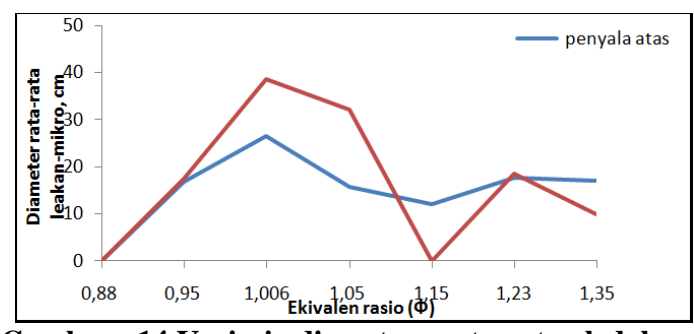

Gambar 14.Variasi diameter rata-rata ledakanmikro maksimum dengan ekivalen pada penyalaan atas dan penyalaan bawah

\section{Kesimpulan}

Dengan mematik campuran uap minyak kelapa-udara dengan reaksi kimia pembakaran akan menghasilkan uap air, gas $\mathrm{CO}_{2}$ dan gas $\mathrm{N}_{2}$. Trigliserida, uap air hasil reaksi kimia pembakaran dipakai untuk reaksi hidrolisa akan menghasilkan gliserol dan asam lemak. Asam lemak dengan reaksi pembakaran akan menghasilkan uap air, dimana uap air diserap oleh gliserol. Dengan ekivalensi rasio $(\Phi)$ yang sama dari bahan bakar minyak kelapa pada penyala atas dan bawah, dimana penyala bawah disebabkan oleh adanya gas $\mathrm{CO}_{2}$ yang bersifat inhibitors. Inhibitors ini merambat ke atas masuk daerah reaksi menyerap panas yang dihasilkan oleh proses pembakaran dan menurunkan temperatur api yang dihasilkan serta menurunkan atau menghambat laju reaksi kimia. Akibat perambatan api, dapat disimpulkan bahwa gas $\mathrm{CO}_{2}$ bisa mempengaruhi terhadap parameterparameter sebagai berikut:

1) Kecepatan rambat api yang disebabkan adanya gradien temperatur, dimana penyala bawah lebih lambat dari penyala atas, hal ini disebabkan oleh gas $\mathrm{CO}_{2}$ yang masuk ke daerah reaksi, sehingga memperlambat kecepatan rambat api.

2) Jumlah ledakan-mikro yang disebabkan uap air diserap oleh gliserol, dimana penyala bawah lebih banyak pada $\Phi=1,35$; $\Phi=1,05$; $\Phi=1,006$ dan $\Phi=0,95$ dari penyala atas, hal ini disebabkan gliserol berkesempatan lebih lama untuk menyerap uap air, sehingga terjadi jumlah ledakan-mikro.

3) Diameter partikel rata-rata ledakan-mikro penyala bawah pada $\Phi=1,006$ lebih besar dari penyala atas, karena gliserol yang menyerap uap air kecepatan rambat api lebih lambat dari pada penyala atas sehingga terjadi diameter partikel rata-rata ledakan-mikro lebih besar dan lebih terang.

4) Volume gas yang terbakar disebabkan oleh konduktivitas bahan bakar, dimana penyala bawah lebih sedikit dari penyala atas, hal ini disebabkan oleh gas $\mathrm{CO}_{2}$ menghambat laju reaksi, sehingga gas yang terbakar berkurang.

5) Panjang rambat api disebabkan oleh gradien kecepatan, dimana penyala bawah lebih panjang, hal ini disebabkan adanya gas $\mathrm{CO}_{2}$ yang menghambat laju reaksi kimia, sehingga pada penyala bawah panjang rambat api lebih panjang.

6) Luas rambat api disebabkan oleh konduktivitas bahan bakar, dimana penyala bawah lebih kecil dari penyala atas, hal ini disebabkan oleh gas $\mathrm{CO}_{2}$ yang menurunkan temperatur, sehingga luas api lebih kecil.

\section{Daftar Pustaka}

[1] Abdulwahid, M., Khalid M. Saqr, Mohsin M. Sies and Haffis Ujir, Diffusive Thermal Instabilities of C4H10-C3H8/Air Laminar Premixed Flames, diffusionfundamentals.org 9 ( 8): 1-8, 2009.

[2] Agarwal D, \& Agarwal A.K., Performance and emission characteristics of jatropha oil (preheated and blends) in a direct injection compression ignition engine. Appl Therm Eng 27:2314-23, 2007.

[3] Cornet, I., \& Nero, W.E., Emulsified Fuels in Compression Ignition Engines. Int. Eng. Chem. 47 (1955) 2133-2141, 1955.

[4] Dee, V., Shaw B.D., Combustion of Propanol-Glycerol Mixture Droplets in Reduced Gravity. Int J Heat Mass Transfer. 47: 4857- 4867, 2004.

[5] Kang, S.H., Baek, S.W., Im, H. G., Effects of heat and momentum losses on the stability of premixed flames in a narrow channel. Combustion Theory and Modelling. Vol. 10, No. 4, August 2006, 659-681

[6] Muniyappa, P. R., Brammer S. C., Noureddini H., Improved Conversion of Plant Oils and Animal Fats into Biodiesel and Co- product. Bioresour Technol. 56:1924, 1996.

[7] Özkan, M, Ergenç A.T, Deniz O., Experimental Performance Analysis of Biodiesel, Traditional Diesel and Biodiesel with Glycerine. Turkish J Eng Env Sci. 29: 89-94, 2005.

[8] Sahoo, PK and Das L.M., Combustion Analysis of Jatropha, Karanja and Polanga Based Biodiesel as Fuel in a Diesel Engine. Fuel. 88: 994-9, 2009.

[9] Wang, S.Y. Fu, L.J. Kung, C.K. Law, , Combustion and microexplosion of collision-merged methanol/alkane droplets. Proceeding of the combustion Institute, Vol 30: 1965-1972, 2005.

[10] Wardana, I. N. G., Combustion Characteristics of Jatropha Oil Droplet at Various Oil Temperatures. Fuel. 89: 659 664, 2010. 
[11] Xu, G, Ikegami M., Honma S., Ikeda K., Ma X., Nagaishi H., Inverse Influence of Initial Diameter on Droplet Burning Rate in Hot and Cold Ambiences: a Thermal Action of Flame in Balance with Heat Loss. Int J Heat Mass Transfer. 46:1155-69, 2003.

[12] Zhang, B. L., Williams F.A., Effects of the Lewis Number of Water Vapor on the Combustion and Extinction of Methanol Drops. Combust Flame. 112: 113-20, 1998. 